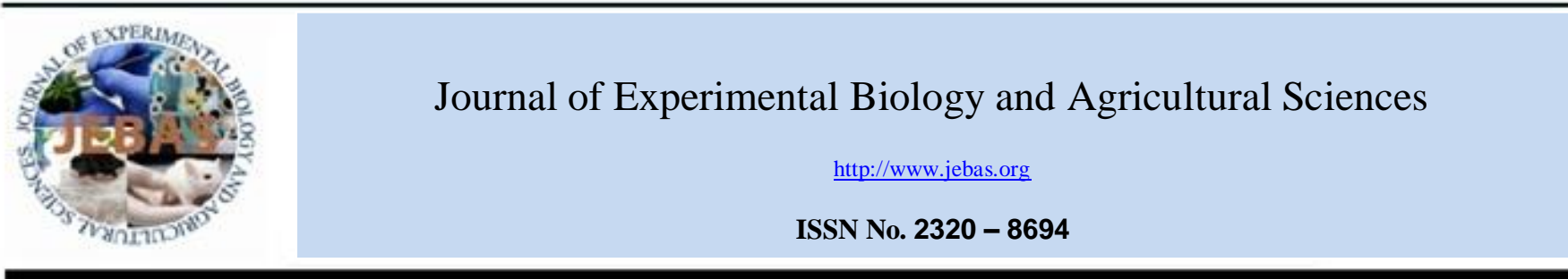

\title{
INFLUENCE OF BIO-FERTILIZER ON GUAVA (Psidium guajava L.) CULTIVATION IN GANGETIC ALLUVIAL PLAIN OF WEST BENGAL, INDIA
}

\author{
Kaushik Das, Sayan Sau*, Pallab Datta, Dipanjana Sengupta
}

Department of Fruits and Orchard Management, Faculty of Horticulture,

Bidhan Chandra Krishi Viswavidyalaya, Mohanpur-741252, Nadia, West Bengal, India

Received - May 22, 2017; Revision - September 01, 2017; Accepted - September 08, 2017

Available Online - September 10, 2017

DOI: http://dx.doi.org/10.18006/2017.5(4).476.482

\section{KEYWORDS}

Guava

Bio-fertilizers

Soil microbial population

Yield

Fruit quality

\begin{abstract}
A field experiment was conducted at the farmer's field, Gayeshpur, Nadia, West Bengal during 2013-15 to study the effect of different bio-fertilizers on yield, fruit quality and leaf mineral composition of guava cv. L-49. The experiment was implemented using a randomized complete-block design with three replicates. Ten treatments of different bio-fertilizers alone and in combinations along with one chemical and absolute control i.e. no fertilization treatment were applied on 6 years old guava plant. Among different treatments of bio fertilizers, Azospirillum brasilense + AMF (Arbuscular mycorhizal fungi) showed highest $(56.30 \%)$ fruit retention and maximum fruit yield $\left(41.3 \mathrm{~kg} \mathrm{plant}^{-1}\right)$ with maximum fruit length, diameter, fruit weight and pulp weight, this was followed by the treatment with Azospirillum brasilense + Bacillus megatherium. The same treatment combination exerted maximum peak in quality parameters like TSS $\left(10.30^{\circ}\right.$ Brix), total sugar $(7.85 \%)$ and ascorbic acid $\left(153.44 \mathrm{mg} 100^{-1} \mathrm{~g}\right.$ of pulp) by increasing the leaf mineral content and soil microbial population substantially. So, for getting higher yield and quality fruit of guava, Azospirillum brasilense + AMF may be a good option for the guavagrowers in gangetic alluvial plain of West Bengal.
\end{abstract}

* Corresponding author

E-mail: sayan.bckv@yahoo.com (Sayan Sau)

Peer review under responsibility of Journal of Experimental Biology and Agricultural Sciences.

Production and Hosting by Horizon Publisher India [HPI] (http://www.horizonpublisherindia.in/).

All rights reserved.
All the article published by Journal of Experimental Biology and Agricultural Sciences is licensed under a Creative Commons Attribution-NonCommercial 4.0 International License Based on a work at www.jebas.org.

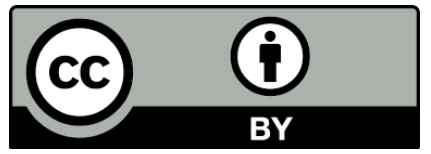




\section{Introduction}

Modern agriculture as well as horticulture has been heavily depending on inorganic fertilizers, pesticides, herbicides and energy intensive farm machinery. Guava (Psidium guajava L.), the apple of the tropics, is a cheap and rich source of vitamin $\mathrm{C}$ and pectin as well as good source of vitamin $\mathrm{A}, \mathrm{B}_{2}$ and minerals like phosphorus, calcium and iron (Dutta et al., 2009). Its cultivation is attaining popularity throughout India as well as in Gangetic plains of West Bengal due to wider adaptability, increasing export potentiality, nutrient richness and scope of production of various value added products (Sharma et al., 2013). Increases in productivity of fruit remove large amounts of essential nutrients from the soil and land began to be intensively exhausted that lead to decline trend in soil fertility and production of less quality fruit. Continuous use of inorganic fertilizers as source of plant nutrients in disproportionate manner resulting in serious damage to the environment and in certain situations harms the plants themselves and also to the consumers (Shanker et al., 2002). Large scale use of chemical fertilizers causes the problem of ground water through leaching, volatilization, denitrification and wastage of nutrients through costly fertilizers. The disproportionate use of chemical fertilizers has widened soil imbalance in terms of NPK and C: N ratio. The occurrence of multi-nutrient deficiencies and overall decline in productivity of the soil has been widely reported due to non-judicious fertilizer use (Chhonkar, 2008). In these circumstances, the entire agricultural community is trying to find out an alternative sustainable farming system which is ecologically sound, economically and socially acceptable (Pathak \& Ram, 2004). Consumer demand for organic tree fruit products in Europe and North America, the dominant organic food markets, has spurred increases in organic area and production globally. From 20082013 , the area of production increased $109 \%, 42 \%$, and $53 \%$ for organic temperate tree fruits, citrus, and tropical/subtropical fruits, respectively (Granatstein et al., 2016). Guava is such a horticultural crop, whose fruits are usually consumed fresh after harvest along with skin and pulp hence, there is feasibility of organic farming in its cultivation. Bio-fertilizer and bio pesticides which are microbial in origin, offer themselves as a viable alternatives for their ability to enrich the soil with beneficial microorganisms; mobilize the nutritionally important elements from non-usable to usable form through biological processes resulting in enhanced production of various fruit crops (Dey et al., 2005). Considering the medicinal importance of guava fruits and plant parts as a whole (Joseph \& Priya 2011), more rational approach to organic cultivation through exploitation of various biofertilizers should be practically implemented to revive the depleted soil fertility and enrich the available pool of nutrients to the plants, which could benefit the crop having long maturity time along with higher economic return. Keeping this in view, the present investigation was undertaken with the objective to study the effect of different bio-fertilizers on yield, fruit quality and leaf mineral composition of guava cv. L-49.

\section{Materials and Methods}

\subsection{Experimental site}

The field experiment was conducted during two successive season of 2013-14 and 2014-15 at the farmer's field, Gayeshpur, Nadia, West Bengal, India $\left(22^{\circ} 56^{\prime} \mathrm{N}, 88^{\circ} 31^{\prime} \mathrm{E}, 9.75 \mathrm{~m}\right.$ above mean sea level). The climate of the region is humid sub-tropical with hothumid summers and cool winters. The mean annual rainfall is $1,750 \mathrm{~mm}$, out of which $80-90 \%$ is normally received from June to September. Soil at the experiment site was sandy clay loam (sand $64.8 \%$, silt $10.4 \%$, and clay $24.8 \%$ ) with a $\mathrm{pH}$ of 6.9 and contained organic carbon of $0.63 \%$, available nitrogen $271.00 \mathrm{~kg}$ $\mathrm{ha}^{-1}$, phosphorus $28.21 \mathrm{~kg} \mathrm{ha}^{-1}$ and potassium $210.00 \mathrm{~kg} \mathrm{ha}^{-1}$. The experiment was conducted in a six year aged well managed guava orchard spaced at $6 \mathrm{~m}$ apart.

\subsection{Experimental design and crop husbandry}

The experiment was laid out in a randomized block design comprising of 10 treatments with 3 replications having 2 plants per replication. Various treatments were nutrient application through various biofertilizer sources viz., Azotobacter chroococcum, Azospirillum brasilense, Bacillus megatherium, AMF (Glomus mosseae), A. chroococcum + B. megatherium, A. chroococcum + AMF, A. brasilense + B. megatherium, A. brasilense + AMF, N:P:K :: 260:320:260 g plant $^{-1}$ year $^{-1}$ and control i.e. without any fertilization. For all the treatments, biofertilizers @ 150 g were mixed with 5 kg FYM to apply around the trunk of a single tree in two splits once in January and again during August as a yearly dose. Treatment with inorganic fertilizer i.e. NPK fertilizer also applied in two half during mentioned time of biofertilizer application. Uniformly healthy plants were selected for this study. Standard package of practices was followed for growing plants and plant protection measures were taken through organic means.

\subsection{Measurements and observations}

Best yield indicator in fruit crops i.e. fruit retention was measured by the formula given by Sau et al., 2016:

Fruit retention $\%=\frac{\text { No. of retained fruits (at harvest) }}{\text { No. of settled fruits initially }} \times 100$

Observations of fruit physical parameters like fruit size (length and diameter) with the help of Vernier Calipers; fruit weight, Pulp and core weight with the help of digital weighing balance was based on random ten fruit samples. Biochemical fruit quality was 
determined from the juice extracted from 10 fruit. The Total Soluble Solid (TSS) was estimated using digital refractometer (ATAGO, RX 5000, Tokyo, Japan) and was expressed as ${ }^{\circ}$ Brix. Titratable acidity was determined by titrating $5 \mathrm{~mL}$ of juice against $0.1 \mathrm{~N} \mathrm{NaOH}$ and expressed as \% (AOAC, 2000). Ascorbic acid ( $\mathrm{mg} 100 \mathrm{~g}^{-1}$ ) content of the guava fruit was estimated by using 2, 6-dichlorophenolindophenol dye titration method (Casanas et al., 2002). Total sugar (\%), reducing sugar (\%) and non-reducing sugar $(\%)$ were determined as per the guidelines of AOAC (2000).

\subsection{Determination of Leaf nutrient content and soil bacterial population}

For determination of leaf mineral contents (N, P and $\mathrm{K}$ ), fifty recently mature $3 \mathrm{rd}$ pair leaves were selected from non-fruiting shoot at random. Leaf samples were washed with ordinary detergent, rinsed well with distilled water and dried in oven at $70^{\circ} \mathrm{C}$ for $48 \mathrm{~h}$. After drying, leaves were grinded into fine powder using electric grinder. Then the powder samples were used for analysing total $\mathrm{N}$ by micro-kjeldhal steam distillation method (AOAC, 2000). The samples were further digested in di-acid (nitric acid - perchloric acid in 9:4 v/v ratio) mixture and used for analysing $\mathrm{P}$ using Vanadomolybdo phosphoric acid method, $\mathrm{K}$ using flame photometer.

To estimate the number of soil bacteria, counts were calculated on the basis of serial 10 fold dilution technique, using the pour plate methods and replicate of $10 \mathrm{gm}$ soil samples, and an appropriate dilution as described by Johnson \& Curl, (1972). Soil bacterial population expressed as Colony forming units per $\mathrm{g}$ of soil (cfu/g) that calculated using the equation of James (1978).

$$
\begin{aligned}
\text { Colony forming unit } & \left(\frac{\mathrm{CFU}}{\mathrm{gm}} \text { soil }\right) \\
& =\frac{\text { No. of colonies } \times \text { dilution factor }}{\text { Volume of inoculum }}
\end{aligned}
$$

\subsection{Statistical analysis}

Statistical assessment was performed by the analysis of variance (ANOVA) for randomized block design (RBD) based on the guidelines given by Gomez \& Gomez (1984). For comparison of ' $F$ ' values and computation of critical difference (CD) at $5 \%$ level of significance, Fisher and Yates' table were consulted. The variances over years were firstly analyzed by homogeneity test by performing Barlett's chi-squre test and pooled analysis of observation are presented to discuss and to draw logical conclusions.

\section{Results and Discussion}

\subsection{Fruit retention and yield of guava cv. L-49}

Data presented in Table 1 revealed that different sources of biofertilizers significantly influenced the fruit retention of guava. Highest fruit retention $(56.30 \%)$ was recorded from the combination of $A$. brasilense $+\mathrm{AMF}$ and this was followed by $A$ brasilense $+B$. megatherium combination $(56.10 \%)$ while control recorded minimum fruit retention $(45.20 \%)$. In the same way highest yield plant $^{-1}\left(41.37 \mathrm{~kg}\right.$ plant $\left.^{-1}\right)$ and highest yield $\mathrm{ha}^{-1}$

\begin{tabular}{|c|c|c|c|}
\hline Treatments & $\begin{array}{c}\text { Fruit retention }(\%) \\
\text { (Arc sin value) }\end{array}$ & Yield plant $^{-1}(\mathrm{~kg})$ & Yield $\mathrm{ha}^{-1}$ (tonnes) \\
\hline Azotobacter chroococcum & $51.00(45.57)$ & 36.15 & 10.04 \\
\hline Azospirillum brasilense & $52.10(46.20)$ & 36.72 & 10.20 \\
\hline Bacillus megatherium & $50.12(45.07)$ & 37.00 & 10.28 \\
\hline AMF (Glomus mosseae) & $53.14(46.80)$ & 37.35 & 9.54 \\
\hline A. chroococcum + B. megatherium & $54.15(47.38)$ & 37.14 & 10.32 \\
\hline A. chroococcum $+\mathrm{AMF}$ & $56.00(48.44)$ & 38.12 & 10.59 \\
\hline A. brasilense + B. megatherium & $56.10(48.50)$ & 40.11 & 11.15 \\
\hline A. brasilense + AMF & $56.30(48.62)$ & 41.37 & 11.50 \\
\hline N:P:K (260:320:260 gplant $^{-1}$ year $\left.^{-1}\right)$ & $51.20(45.69)$ & 32.40 & 9.00 \\
\hline Control & $45.20(42.25)$ & 25.20 & 7.00 \\
\hline $\mathrm{SEm} \pm$ & 0.678 & 1.385 & 0.548 \\
\hline $\mathrm{CD}(p=0.05)$ & 2.015 & 4.114 & 1.64 \\
\hline
\end{tabular}

Table 1 Effect of different bio-fertilizers on fruit retention and yield of guava cv. L-49 (Pooled data of two years)

$\left(11.50\right.$ tonnes $\left.\mathrm{ha}^{-1}\right)$ were also recorded from A. brasilense $+\mathrm{AMF}$ 
combination which was followed by the combined application of A. brasilense $+B$. megatherium $\left(40.11 \mathrm{~kg} \mathrm{plant}^{-1}\right.$ and 11.15 tonnes $\left.\mathrm{ha}^{-1}\right)$ while yield from control was recorded minimum $(25.20 \mathrm{~kg}$ plant $^{-1}$ and 7 tonnes $\mathrm{ha}^{-1}$ ). An increased level of fruit retention up to $24.55 \%$ and subsequently higher yield of $64.28 \%$ was recorded in the best treatment (A. brasilense + AMF) over the control. Similar result of improved fruit retention and yield with the application of biofertilizer was observed by several researchers in guava (Ram et al., 2007; Barne et al., 2013). Increasing productivity of various crops for utilization of organic fertiliser could be better preposition for improving biological attributes of soil, which in turn may increase productivity of various crops (Allen et al., 2002).The increase in fruit retention and yield with bio-fertilizer may be due to the build up of colonies of the applied bio-fertilizer inoculates and their growth promoting effects including the synthesis of plant growth promoting substances to enhance photosynthetic activity (Dutta et al., 2009).

\subsection{Physical characters of guava fruits cv. L-49}

It is evident from the data as shown in Table 2 that different combination of bio-fertilizers significantly affected the fruit length, fruit weight, core weight and pulp weight of guava. But the treatments have no significant effect on fruit diameter. Here also A. brasilense + AMF gave maximum fruit length $(8.49 \mathrm{~cm})$, fruit diameter $(7.11 \mathrm{~cm})$, fruit weight $(143.43 \mathrm{~g})$, core weight $(45.3 \mathrm{~g})$ and pulp weight $(98.11 \mathrm{~g})$ and this was followed by the combined application of $A$. brasilense $+B$. megatherium while control recorded minimum values in all cases. These results are in conformity of previous observation depicted by Dey et al. (2005), Ram et al. (2007), Binepal et al. (2013) in their experiment on guava with different biofertilizer. Biofertilizer is considered as a significant source of different micronutrients which play an important role in regulation of length and diameter of guava by enhancing metabolic activities in plant cells (Sharma et al., 2013). Thus guava fertilized with biofertilizer produced larger sized fruit than plant received inorganic or not any fertilizer (control).

\subsection{Biochemical composition of guava fruits cv. L-49}

With regards to chemical composition of fruits, data presented in the Table 3 revealed that different treatments of bio fertilizer did not significantly influence the total soluble solids, total sugar and reducing sugar content of guava fruit. However treatment containing A. brasilense + AMF showed maximum TSS $\left(10.30^{\circ}\right.$ Brix), total sugar $(7.85 \%)$ and reducing sugar $(4.37 \%)$ which was followed by the combined application of $A$. chroococcum $+B$. megatherium) and $A$. brasilense $+B$. megatherium. Other quality parameters like non reducing sugar, ascorbic acid and titrable acidity of fruit were significantly influenced by different treatments of bio-fertilizers. Among the different treatments, here also A. brasilense+ AMF showed maximum non-reducing sugar $(3.48 \%)$ and ascorbic acid $\left(153.44 \mathrm{mg} 100^{-1} \mathrm{~g}\right)$ with less acidity $(0.27 \%)$ whereas the fruits treated with chemical fertilizers were found to have the maximum acidity of $0.38 \%$. The fruits from control plants recorded minimum for all the biochemical parameters. These findings are in consonance with result of several earlier researchers like Yadav et al. (2012), Varsha et al. (2011) and Sharma et al. (2013). The improved fruit quality may be attributed to better vegetative growth of the treated plants, which resulted in higher quantities of photosynthates (starch, carbohydrates etc.) and the translocation to the fruits

Table 2 Effect of different bio-fertilizers on physical characters of guava fruit cv. L-49 (Pooled data of two years)

\begin{tabular}{|c|c|c|c|c|c|}
\hline Treatments & $\begin{array}{l}\text { Fruit length } \\
\text { (cm) }\end{array}$ & $\begin{array}{c}\text { Fruit Diameter } \\
(\mathbf{c m})\end{array}$ & $\begin{array}{c}\text { Fruit weight } \\
\text { (g) }\end{array}$ & $\begin{array}{c}\text { Core weight } \\
\text { (g) }\end{array}$ & $\begin{array}{l}\text { Pulp weight } \\
\text { (g) }\end{array}$ \\
\hline Azotobacter chroococcum & 7.12 & 6.41 & 131.44 & 36.72 & 94.72 \\
\hline Azospirillum brasilense & 7.49 & 6.00 & 137.14 & 41.28 & 95.86 \\
\hline Bacillus megatherium & 7.92 & 6.71 & 130.51 & 36.74 & 93.77 \\
\hline AMF (Glomus mosseae) & 7.00 & 6.10 & 130.40 & 35.48 & 94.92 \\
\hline A. chroococcum + B. megatherium & 7.42 & 6.31 & 138.41 & 43.42 & 94.99 \\
\hline A. chroococcum + AMF & 8.11 & 6.41 & 139.72 & 44.41 & 95.31 \\
\hline A. brasilense + B. megatherium & 8.40 & 6.39 & 140.41 & 43.0 & 97.41 \\
\hline A. brasilense $+\mathrm{AMF}$ & 8.49 & 7.11 & 143.43 & 45.32 & 98.11 \\
\hline N:P:K (260:320:260 g plant ${ }^{-1}$ year $\left.^{-1}\right)$ & 7.41 & 6.91 & 134.41 & 39.71 & 94.70 \\
\hline Control & 6.93 & 5.95 & 130.34 & 40.93 & 89.41 \\
\hline $\operatorname{SEm} \pm$ & 0.00 & 0.33 & 0.96 & 0.444 & 0.78 \\
\hline $\mathrm{CD}(p=0.05)$ & NS & NS & 2.86 & 1.319 & 2.33 \\
\hline
\end{tabular}


Table 3 Effect of different bio-fertilizers on bio-chemical composition of guava fruit cv. L-49 (Pooled data of two years)

\begin{tabular}{|c|c|c|c|c|c|c|}
\hline Treatments & $\begin{array}{c}\text { TSS } \\
\left({ }^{\circ} \text { Brix }\right)\end{array}$ & $\begin{array}{c}\text { Total } \\
\text { Sugar }(\%)\end{array}$ & $\begin{array}{l}\text { Reducing } \\
\text { sugar }(\%)\end{array}$ & $\begin{array}{l}\text { Non-reducing } \\
\text { sugar }(\%)\end{array}$ & $\begin{array}{c}\text { Ascorbic acid } \\
\text { (mg } 100 \mathrm{~g}^{-1} \text { of pulp) }\end{array}$ & $\begin{array}{c}\text { Titrable } \\
\text { acidity }(\%)\end{array}$ \\
\hline Azotobacter chroococcum & 9.90 & 6.79 & 3.95 & 2.84 & 125.25 & 0.29 \\
\hline Azospirillum brasilense & 9.80 & 6.97 & 3.99 & 2.98 & 130.12 & 0.31 \\
\hline Bacillus megatherium & 10.0 & 7.10 & 4.22 & 2.88 & 128.41 & 0.28 \\
\hline AMF (Glomus mosseae) & 9.70 & 6.95 & 3.84 & 3.11 & 128.00 & 0.26 \\
\hline A. chroococcum + B. megatherium & 10.1 & 7.44 & 4.11 & 3.33 & 137.44 & 0.31 \\
\hline A. chroococcum $+\mathrm{AMF}$ & 10.0 & 7.19 & 4.00 & 3.19 & 139.44 & 0.28 \\
\hline A. brasilense + B. megatherium & 10.1 & 7.22 & 4.11 & 3.11 & 141.72 & 0.26 \\
\hline A. brasilense + AMF & 10.3 & 7.85 & 4.37 & 3.48 & 153.44 & 0.27 \\
\hline N:P:K (260:320:260 g plant ${ }^{-1}$ year $\left.^{-1}\right)$ & 9.10 & 6.21 & 3.88 & 2.33 & 114.72 & 0.38 \\
\hline Control & 9.00 & 6.11 & 3.67 & 2.44 & 110.42 & 0.32 \\
\hline SEm \pm & 1.532 & 0.339 & 0.208 & 0.122 & 0.313 & 0.009 \\
\hline $\mathrm{CD}(p=0.05)$ & NS & NS & NS & 0.362 & 0.93 & 0.027 \\
\hline
\end{tabular}

Table 4 Effect of different bio-fertilizers on leaf mineral (N, P and K) content and soil microbial population (Pooled data of two years)

\begin{tabular}{|c|c|c|c|c|}
\hline Treatments & $\begin{array}{c}\mathrm{N}(\% \text { dry } \\
\text { weight) }\end{array}$ & $\begin{array}{l}\mathrm{P}(\% \text { dry } \\
\text { weight })\end{array}$ & $\begin{array}{l}\mathrm{K}(\% \text { dry } \\
\text { weight }\end{array}$ & $\begin{array}{l}\text { Soil microbial population bacteria } \\
\text { (cfu g } \mathrm{g}^{-1} \text { of soil) }\end{array}$ \\
\hline Azotobacter chroococcum & 1.41 & 0.38 & 1.11 & $5.9 \times 10^{6}$ \\
\hline Azospirillum brasilense & 1.47 & 0.41 & 1.12 & $6.0 \times 10^{6}$ \\
\hline Bacillus megatherium & 1.48 & 0.40 & 1.02 & $6.1 \times 10^{6}$ \\
\hline AMF (Glomus mosseae) & 1.50 & 0.49 & 1.13 & $5.8 \times 10^{6}$ \\
\hline A. chroococcum + B. megatherium & 1.49 & 0.49 & 1.14 & $6.3 \times 10^{6}$ \\
\hline A. chroococcum $+\mathrm{AMF}$ & 1.59 & 0.47 & 1.17 & $6.1 \times 10^{6}$ \\
\hline A. brasilense+ B. megatherium & 1.56 & 0.43 & 1.12 & $6.1 \times 10^{6}$ \\
\hline A. brasilense + $\mathrm{AMF}$ & 1.61 & 0.44 & 1.19 & $6.7 \times 10^{6}$ \\
\hline N:P:K $\left(260: 320: 260\right.$ g plant $^{-1}$ year $\left.^{-1}\right)$ & 1.31 & 0.37 & 1.11 & $2.8 \times 10^{6}$ \\
\hline Control & 1.21 & 0.31 & 0.97 & $2.9 \times 10^{6}$ \\
\hline $\mathrm{SEm} \pm$ & 0.01 & 0.03 & 0.01 & 51704.3 \\
\hline $\mathrm{CD}(p=0.05)$ & 0.03 & 0.10 & 0.02 & 153.59 \\
\hline
\end{tabular}

(Naik \& Haribabu, 2007). Increase in physicochemical parameters of fruits might be on account of influential role of bio-fertilizer in higher nitrogen fixation and uptake of nitrogen thereby stimulating the catalytic activity number of enzymes in the physiological processes and increasing production of sugars and amino acids that ultimately increase the total soluble solid, sugar and ascorbic acid content of the fruits (Dutta \& Kundu, 2012).

\section{population}

The effect of improved soil nutrient availability coupled with better physical conditions of soil was reflected in increased uptake of macro nutrients under different biofertilizers treatments (Table 4). Experiment data showed that leaf $\mathrm{N}$ content significantly varied from 1.21 to $1.64 \%$ and was maximum with the application of A. brasilense + AMF. Similarly maximum leaf 
$\mathrm{P}(0.49 \%)$ and $\mathrm{K}(1.19 \%)$ contents were observed in same treatment. Increased leaf mineral nutrients by the application of different bio-fertilizers might be due to greater solubility, increased root surface to volume and permeation of hypal pads patch beyond explored by root hairs. The greater multiplication of microbes in biofertilizers converted organically bound $\mathrm{N}$ to organic form and increased uptake of N (Chauhan, 2008). Addition of biofertilizer induced production of oxalic acid by the plants that resulted in mobilization of immobile soil $\mathrm{P}$ and helped in increasing the uptake of P by the plants (Dotaniya et al., 2014; McDowell et al., 2000). Increased macronutrient uptake with the application of biofertilizer was reported in several fruit crops viz. guava (Trivedi et al., 2012; Ram et al., 2007), sweet orange (Marathe et al., 2012), mango (Dutta \& Kundu, 2012) and Litchi (Anubha et al., 2013).

The data pertaining to the influence of different sources of biofertilizers in Table 4 revealed microbial population of soil were significantly varied due to different treatments. Soil from tree basin of A. brasilense+ AMF treated plants recorded highest microbial population of soil bacteria $\left(6.7 \times 10^{6} \mathrm{cfu}^{-1}\right.$ of soil) may be due to their higher multiplication rate and this was followed by A. chroococcum + B. megatherium while minimum bacterial population was measured in plant treated by inorganic fertilizer source.

\section{Conclusions}

The results of this study unravelled that the quality requirement of guava could be fulfilled with the exclusive use of biofertilizer with improved growth performance and yield. Among different combinations of bio-fertilizers, A. brasilense + AMF proved most effective in rendering quality fruit production keeping soil health condition in a better state with increasing microbial population. Thus combined application of $150 \mathrm{~g}$ of A. brasilense and AMF along with $5 \mathrm{~kg}$ of FYM in two split application (one at January and other during August) is prescribed for higher quality fruit production of guava in an organic manner.

\section{Conflict of interest}

Authors would hereby like to declare that there is no conflict of interests that could possibly arise.

\section{References}

Allen MF, Jasper DA, Zak JC (2002) Chapter 14, Microorganisms. In: Devi AJ, Perrow M (Eds) Handbook of Ecological Restoration Vol. Principle of restoration, part 4, Manipulation of bioth, Cambridge University Press, Pp 257-78.
Anubha R, Lal RL, Uniyal S, Chand S (2013) Response of organic manures on growth, nutrient status and yield of Litchi (Litchi chinensis Sonn.) cv. Rose Scented. Progressive Horticulture 45:126-131.

AOAC (2000) Association of Official Agricultural Chemists, Official Methods of Analysis, 15th ed. A.O.A.C., Washington, DC.

Barne VG, Bharad SG, Dod VN, Baviskar MN (2013) Effect of integrated nutrient management on yield and quality of guava. Asian Journal of Horticulture 6:546-548.

Binepal MK, Tiwari R, Kumawat BR (2013) Effect of integrated nutrient management on physico-chemical parameters of guava under Malwa plateau conditions of Madhya Pradesh. Annals of Plant and Soil Research 15:47-49.

Casan as RR, Gonza'lez M, Rodri'guez E, Marrero A, Di'az C (2002) Chemometric Studies of Chemical Compounds in Five Cultivars of Potatoes from Tenerife. Journal of Agricultural and Food Chemistry 50: 2076-2082.

Chauhan A (2008) Studies on integrated nutrient management in plum (Prunus salicina L.) cv. Santa Rosa. In: Ph.D. Thesis submitted to the Dr. Y.S. Parmar University of Horticulture and Forestry, Nauni, Solan, India.

Chhonkar PK (2008) Organic farming and its relevance in India. Organic agriculture. Indian Society of Soil Science. Jodhpur. Pp:5-33.

Dey P, Rai M, Nath V, Das B, Reddy NN (2005) Effect of biofertilizer on physico-chemical characteristics of guava (Psidium guajava L.) fruit. Indian Journal of Agricultural Sciences 75: 95-96.

Dotaniya ML, Datta SC, Biswas DR, Meena HM, Kumar K (2014) Production of oxalic acid as influenced by the application of organic residue and its effect on phosphorus uptake by wheat (Triticum aestivum L.) in an inceptisol of North India. National Academic Science Literature 37:401-405.

Dutta P, Kundu S (2012) Effect of bio-fertilizers on nutrient status and fruit quality of Himsagar mango grown in new alluvial zones of West Bengal. Journal of Crop and Weed 8:72-74.

Dutta P, Maji SB, Das BC (2009) Studies on the response of biofertilizers on growth and productivity of guava. Indian Journal of Horticulture 66:39-42.

Gomez KA, Gomez AA (1984) Statistical procedures for Agricultural Research, John Willey and Sons, New York. 
Granatstein D, Kirby E, Ostenson H, Willer H (2016) Global situation for organic tree fruits. Scientia Horticulturae 208:3-12.

James GC (1978) Natallic Sherman Rockland Community College,State University of New York, The Benjamin/Coming publishing Company, Pp. 75-80

Johnson LF, Curl EA (1972) Methods for Research on the Ecology of Soil-Borne Plant Pathogens. Burgess, Minneapolis, MN, pp. 7-14.

Joseph B, Priya M (2011) Review on nutritional, medicinal and pharmacological properties of guava (Psidium guajava Linn.).International Journal of Pharma \& Biosciences, 2, 53-69.

Marathe RA, Bharambe PR, Sharma R, Sharma UC (2012) Leaf nutrient composition, its correlation with yield and quality of sweet orange and soil microbial population as influenced by INM in Vertisol of central India. Indian Journal of Horticulture 69:317321.

McDowell RW, Condron LM, Stewart I (2000) An examination of potential extraction methods to assess plant-available organic phosphorus in soil. Biology and Fertility of Soils 44: 707-716.

Naik MH, Haribabu R (2007) Feasibility of organic farming in guava (Psidium guajava L.). Acta Horticulture 735: 365-372.

Pathak RK, Ram RA (2004) Organic farming systems prevalent in India. National Symposium on Organic farming in Horticulture for Sustainable Production, Souvenir, pp. 18-26.
Ram RA, Bhriguvanshi SR, Pathak, RK (2007) Integrated plant nutrient management in Guava (Psidium guajava L.) cv. Sardar. Acta Horticulture 735:345-350.

Sau S, Ghosh B, Sarkar S (2016) Correlation and path analysis studies for growth and yield contributing traits in guava (Psidium guajava L.) as affected by micronutrient application. Annals of Plant and Soil Research 18: 370-374.

Shanker U, Pathak RA, Pathak RK, Ojha CM, Shanker U (2002) Effect of NPK on the yield and fruit quality of guava cv. Sardar. Progressive Horticulture 34: 49-55.

Sharma A, Wali VK, Bakshi P, Jasrotia A (2013) Effect of integrated nutrient management strategies on nutrient status, yield and quality of guava. Indian Journal of Horticulture 70:333-339.

Trivedi YV, Patel NL, Ahlawat TR, Gaikwad SS, Bhalerao PP (2012) Impact of organic manures and inorganic fertilizers on growth, yield, nutrient uptake and soil nutrient status in guava. Indian Journal Horticulture 69 : 501-506.

Varsha GB, Bharad SG, Dod VN, Baviskar MN (2011) Effect of integrated nutrient management on yield and quality of Guava. The Asian Journal of Horticulture 6:546- 548.

Yadav RI, Singh RK, Kumar P, Singh AK (2012) Effect of nutrient management through organic sources on the productivity of guava. Hort Flora Research Spectrum 1 : 158-161. 